\title{
Does Ownership Structure Improve Financial Reporting Quality? Evidence Of Real Earnings Manipulation Among Pakistani Firms
}

\author{
SYED FARHAN SHAH*, ABDUL RASHID, WASIM SHAHID MALIK \& FAISAL \\ SHAHZAD
}

\begin{abstract}
This paper examines whether ownership structure improve the financial reporting quality. We built on two different econometric techniques including Feasible Generalized Least Square (FGLS) and Panel Corrected Standard error Model (PCSE) by using a sample of 150 non-financial firms listed on Pakistan Stock exchange for the period of 20082017. The results propose that institutional ownership and as well as managerial ownership are negatively related to real earnings manipulation, which implies that both these types of ownership structure act as a best monitoring mechanism in reducing real earnings manipulation and thus enhancing the financial reporting quality. Whereas, state ownership and family ownership are positively associated to real earnings manipulation, which suggest that family and state ownerships engage in real earnings manipulation and thus reducing the financial reporting quality. Overall results supports the alignment hypothesis, entrenchment effect and efficient monitoring hypothesis of the agency theory. The results of the study provide practical implication for investors and policymakers in understanding the role of ownership on financial reporting quality.
\end{abstract}

Keywords: Ownership Structure; Financial Reporting Quality; Real Earnings Manipulation; Agency Theory

\section{INTRODUCTION}

Governance and transparency are the two key challenges faced by developing countries. Most academics view these as the key differentiators between developed and developing countries. Corporate governance (CG) is considered as a controlling mechanism structure through which firms are organized and supervised. One important aspect of this controlling mechanism is ownership structure. According to Wajid and Shah (2017), CG main role is to guard the interest of shareholders especially in those countries having a very weak legal system like Pakistan. The credibility of financial information and accounting income have gained a lot of attention among companies and regulatory bodies in recent time around the world in the framework of corporate control (Rafique et al. 2017). Strong CG mechanism mitigates the conflict between managers and shareholders (Shah et al. 2019). According to Lins and Warnock (2004), in general, the mechanisms that can control the opportunistic behavior of management, can be categorized into two types. One is the internal company (ownership structure and corporate control structure), and the second is external company (law and market of corporate control). The agency costs remain lesser in companies with high management shares in equity, as this allows unification of interests of shareholders and the managers (Jensen \& Meckling 1976).

Healy and Wahlen (1999) indicated that earnings manipulation occurs when management adjust and smoothens companies earnings using their own judgement for the purpose of enhancing the company performance and deceive shareholders about accounting information. Information enclosed in financial reports need to be useful and valuable that can be used as a reference to forecast the state of the company in the future. This will be crucial for all the stake holders which enables them to monitor the company operation.

Currently managers are required to adjust the recording of financial reporting with the global standard of International Financial Reporting Standards (IFRS) with the intention to bring uniformity in the financial data and boosts the excellence \& transparency of accounting data, so that useful information should be provided to the users (Affan et al. 2017). Kaldonski et al. (2019) argued that managers manipulate earnings via discretionary accruals termed as accrual earnings management (AEM) and through cutting research and development and advertising expenses or increasing the sales through offering a large sales discounts that upset both income and cash flows referred as manipulation through real activities (REM). Sakaki et al. (2017) argued that earnings manipulation through real activities is more dangerous to the survival of the companies as they effect the long term profitability and value of the company. 
According to Farouk and Bashir (2017), ownership has been identified by extant literature to be a useful controlling tool through which managers' opportunistic behavior can be controlled. Ownership structure consist of two broad aspect in context of number of shares held, one is shares owned by outsiders versus insiders and number of shares owned by institutions versus individuals (Parveen et al. 2016). In Pakistan, the agency cost not only arise due to the managers-owners conflict, but the agency cost also resulted in the encounter between governing and nongoverning shareholders and such conflict is more sever in the developing countries where investors protection rights are very weak and the ownership structure is very concentrated (Arshad \& Javid 2014).

Most of the previous studies used an accrual quality of earnings to measure the financial reporting quality to examine the influence of ownership on income manipulation and financial reporting quality (Farouk \& Bashir 2017; Alzoubi 2016; Adebiyi \& Olowookere 2016; Yasmeen \& Hermawati 2015 \& Rafique et al. 2017). According to Shayan-Nia et al. (2017), managers are shifting towards income manipulation through REM as it is harder to be identified by an external auditors in comparison to manipulation through AEM. Keeping in view this research study uses income manipulation by managers through real earnings manipulation in the Pakistani firms to measure the financial reporting quality. The results of study will be significant to regulatory bodies and investors that are concerned to the excellence of the financial reports.

This study has the following contribution; first, this paper prolongs and compliments the limited literature on ownership structure and financial reporting quality via real earnings manipulation in Pakistan. To our finest understanding this is a pioneer study which examines the influence and role of ownership structure attributes on controlling earnings manipulation through real earnings management. Most of the previous studies (Nazir \& Afza 2018; Abid et al. 2018; Rafique et al. 2017) explore the role of ownership structure on earnings manipulation in the context of accrual earnings management in Pakistan. Second this research will help to discover the effectiveness of ownership structure in controlling the opportunistic behavior of the manager by covering all the important aspect of ownership structure in Pakistan that make it more comprehensive research studies in the framework of ownership identity and real earnings manipulation. Thirdly, the previous studies (Farouk \& Bashir 2017; Alzoubi 2016; Adebiyi \& Olowookere 2016; Abid et al. 2018) have ignored the cross-sectional dependence in the model. Ignoring the cross sectional dependence could have serious consequences and the results of conventional panel estimates such as fixed and random effect and even the GMM can result in ambiguous inference and even unreliable estimators (Sarafidis \& Robertson 2009; Shahzad et al. 2017). The current study, however used the feasible generalized least square (FGLS) and Panel corrected standard error (PCSE) techniques in dealing with panel autocorrelation, heteroscedasticity and cross sectional dependence

The study finds that managerial ownership and institutional ownership structure act as a strong internal control system in reducing income manipulation through real earnings management and thus enhancing the financial reporting quality. Whereas, state ownership and family ownership are positively linked to earnings manipulation, which suggest that family and state-ownerships engage in income manipulation through real earnings management.

The remaining study arranged as follow; Section 2 outlines the literature and hypotheses development, Section 3 is about the methodological approach used in the study including Section 4 reports and explains the empirical results. Finally, Section 5 documents the conclusion and recommendations.

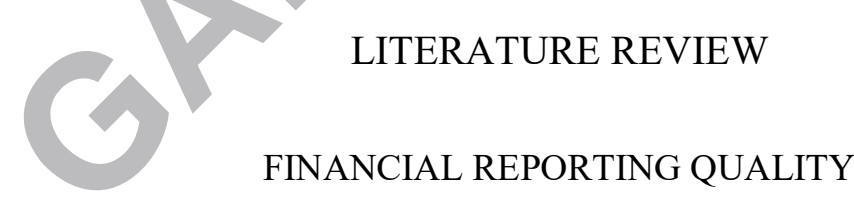

According to Zeff (2013), financial reporting quality is very significant for the strategic decision making. The significant decision effectiveness truly means that appropriate and trustworthy data is presented to the users so that they can make a best decision for the survival and profitability of the firms. Both internal and external stake holders that includes shareholders, creditors and regulators are the main user of the financial reports and they utilizes these reports for future decision making. The shareholder through financial reporting makes decision to assess the future cash flows of the project in which companies are interested to invest. According to Healey and Palepu (2001), one of the main sources through which management communicates its performance to the outsiders and other stakeholders is through financial reporting. For a capital market to function efficiently, the coordinated and transparent financial reports are very important. The firm's performance is communicated to the shareholders by providing transparent earnings quality. The information asymmetry amongst the managers and outside investors give rise to demand for credible and transparent financial reports through which the firm's performance can be analyzed. So, it is clear that the financial reporting is considered as a vital means among a firm's and numerous investors. 
According to Francis et al. (2004), two attributes have been used in the previous literature as a proxy of financial reporting quality (FRQ). One is accounting-based earnings attributes like accrual quality, income smoothing and earnings persistence and second is market-based earnings attributes like value relevance and conservatism. In the accounting-based earnings attributes the managers allocate the cash flow to reported period via accrual process and cash flow or earnings are directly derived from the accounting information. While market-based attributes take price or return as a reference construct information directly. The fundamental assumption of the market base attribute is that it considers earnings as the firm economic income. "Financial reporting quality is a set of complete facts which signifies a factual depiction of the firm (IASB (2010)."

Joanas and Blachet (2000) argued that FRQ have two different aspects. One is user need perspective and that other is shareholder/investor perspective. The user needs perspective is very useful in economic decision as it provides relevant and true information to the financial statement users. On the other hand, shareholder/investor perspective is useful in mitigating the information symmetry and provides very useful and true information to the decision makers and shareholders. According to Dechow et al. (2010), there is no single best measure of FRQ. The leading source of information is earnings, so most of the financial statement users' value more to earnings as compared to other accounting figures (Francis et al. 2004). Accounting literature presents several definitions related to the quality of financial information, as it represents multi-dimensional concept (Gaio 2010). The diversity among the different dimension and definition about the quality of earnings is due to the fact that they are used by different users for different decisions (Kirschenheiter \& Melumad 2004).

\section{REAL EARNINGS MANIPULATION AS MEASURE OF FINANCIAL REPORTING QUALITY}

Dechow et al. (2010) argued that due to different classification of earnings, there are very varied measures of FRQ. As the leading source of information is earnings, so most of the financial statement users value more to earnings as corresponding to other accounting figures (Francis et al 2004). Accounting literature presents several definition about the financial reporting, as it represents multi-dimensional concept (Gaio 2010). The diversity among the different dimension and definition about the quality of earnings is due to the fact that they are used by different users for different decisions (Kirschenheiter \& Melumad 2004).

According to Graham et al. (2005) managers choose real earnings manipulation (REM) more to manipulate earnings as compared to accrual earnings management (AEM). There are different techniques for income manipulation through real activities like, reduction of sales prices to conceal the possible loss and earnings, selling of fixed assets or any other securities for the purpose of achieving earnings target (Hermann et al 2003; Jackson \& Wilcox 2000). Cheng et al. (2013) argued that REM is more prominent when managers have the preference of to enhance the short term performance over the long term firm's value. Through REM the managers manipulate earnings by offering more sales discounts or offering very favorable credit conditions to the customer to surge sales. In addition, to reduce the overall expenses in the income statement the managers reduce discretionary expenses like research and development expenses, and selling, general and administrative expenses opportunistically (Dechow \& Skinner 2000). As reducing research and development expenditure, sales decisions and production volumes are directly under the influence of executives and managers, thus they can easily control and influence such real activities to manipulate earnings (Baderschter 2011). Cohen and Zarowin (2010) argued that in REM, the managers deviate from the normal business activities that have severe economic consequences. Due to its direct impact on firm performance and value, REM is regarded as more dangerous compared to AEM (Bedersher 2011; Sakaki et al. 2017). Thus, the main intention behind the REM is that it is purposeful in nature and have serious consequences on the actual cash flow of the firm. This paper uses Roychowdhury Model (2006) of measuring real earnings manipulation (REM) as proxy for measuring financial reporting quality. Higher the REM, lowers are the financial reporting quality and vice-versa.

\section{HYPOTHESES DEVELOPMENT}

\section{MANAGERIAL OWNERSHIP AND FINANCIAL REPORTING QUALITY}

Advocate of the agency theory argue that separation between principles and agent creates information asymmetries between these two parties (Jensen \& Meckling 1976). Manager's opportunistic behavior increases when they do not own any stake in the firm which ultimately open window of opportunity for earnings manipulation. (Fama 1980; Fama \& Jensen 1983; Jensen and Meckling 1976). However, when managers have not substantial stake in the company ownership they have greater tendency to act and pursue their self-interest, thus reducing the company overall value 
and profitability (Fan \& Wong 2012). Decision making is very poor in those firms where the goals of principals and agents are not align. According to Alves (2012), the managers most of the time hide the actual performance of the firms and manipulate the financial data to mask the poor performance and mislead the stakeholders about the firm performance.

In literature the hypothesis relating to managerial ownership is addressed from dual perspectives of the agency relationship of equity. The first type is referred as type-I which represents the affiliation amongst owners and management. Whereas, the affiliation among majority (Controlling) shareholders and minority (non-controlling) shareholders referred as type II agency relationship (Ali et al. 2007). The traditional aspect is that high managerial ownership actually limits the adaptable behavior of the management thus increases the company share price and profitability in long run (Fama \& Jensen 1983; Yang et al. 2008). The influence of managerial ownership on financial reporting quality in the previous studies are also mixed in light of the alignment and entrenchment effect. Alves (2012) studied the effect of inside ownership on discretionary accrual (measure of financial reporting quality) of the 34 Portuguese companies and indicated that larger stake of managers in the company share enhances the financial reporting quality. They act as a strong monitoring mechanism to control the income manipulation strategies.

Hashim and Devi (2008) conducted a research of 260 Malaysian companies and determined that larger the management ownership better is the quality of reported income. Similar result was also concluded by Alzoubi (2016) and documented that managerial ownership enhances the reporting quality and limits the earnings manipulation. Whereas on the other sides Ogbonnaya, Chidiebere and Ihendinihu (2016) established that earnings manipulation is positively correlated to managerial ownership structure. Ayadi (2014) inspected the association between income smoothness and insider ownership of the French companies and found that insider ownership reduces the quality of financial data. Similarly, Obigbemi (2017) study documented that earnings manipulation is more prominent in those companies in Nigeria that have high managerial ownership. The above arguments concludes the following hypothesis;

H1: Managerial Ownership is positively related with financial reporting quality (negatively related with REM)

\section{INSTITUTIONAL OWNERSHIP AND FINANCIAL REPORTING QUALITY}

In recent time period the institutional stakeholders are considered as one of the important aspect of controlling mechanism that can shield the minority shareholders rights. Due to the high investment, knowledge and expertise the institutional shareholders can actively monitor the management as compared to non-institutional shareholders (Daily et al. 2003). Kazemian and Sanusi (2015) argued that institutional investors due to their expertise, knowledge and resources act as a strong monitoring mechanism in governing the managers to manipulate income for their self-benefit. According to Man and Wong (2013), institutional investors are passive investors who are more likely to with draw their stake from the poor performing companies than to spend their resources in observing and improving the performance.

According to Claessens and Fan (2002), one of the advantage of the institutional shareholders is that they reduce the agency cost by mitigating the conflict between majority and minority as they guard the rights of minor shareholders. Chung et al. (2005) argued that efficient monitoring hypothesis suggest that institutional investors mostly focus on long term profitability of the firms, so they are associated with better monitoring and reduces the ability of the managers to manipulate earnings opportunistically. Shayan-Nia et al. (2017) argued that institutional investors are of two categories. One category of institutional investors are those who holds a stock for a longer period. These institutional shareholders are very keen to monitor the company operation and want improved firm value. These types of investors mostly focus on long term profitability, so they monitors the management actively (Bushee 2001; Velury \& Jenkins 2006). On the other side those institutional shareholders with short term investment (also called 'myopic investors') focus on the short term gains and immediately liquidate their holding if they do not get their desired level of returns, so they are least interested in the monitoring role (Bushee 1998).

Regarding the empirical results, Aygun et al. (2014) concluded that institutional investors actively monitors the management and controls the income manipulation and enhances the earnings quality in the Pakistani firms. Liu and Tsai (2015) examined the impact of ownership on financial reporting quality proxied by REM in Taiwan. The study concluded that institutional ownerships have negative and significant effect in curtailing real earnings manipulation. Chung et al. (2002) documented the negative relationship and argue that institutional investors strictly monitors the accounting information, thus supports the efficient market hypothesis. Abdullah (1999) found that institutional ownership reduces the earnings quality in the Malaysian firms, supporting the myopic investor hypothesis that investors in Malaysia favors short term return as compared to long term profitability. Balsam et al. (2000) argued that 
due to the expertise and the access to timely information institutional shareholders are in superior situation to govern any deviation in accounting data by management as compared to non-institutional shareholders.

Roodposhti and Chashmi (2011) investigated the impact of institutional investors on income manipulation in the Iranian firms and concluded that institutional investors fails to control the devious conduct of the management. Pongsaporamat (2016) empirically investigated the association between institutional shareholders and income manipulation of the Thai firms and concluded that large institutional ownership fails to curb the management behavior of manipulation of income and thus reducing the quality of financial reports. Ayadi and Boujelbene (2015) study the impact of institutional ownership on earnings quality of 117 French companies and documented that institutional shareholders have no power to control the income manipulation and reporting quality. According to the mixed results, this study conclude the following hypothesis.

H2: Institutional Ownership is positively related to financial reporting quality (negatively related to REM)

\section{STATE OWNERSHIP AND FINANCIAL REPORTING QUALITY}

Two different perspective concerning the state ownership in the literature. One view states that state-owned enterprises mostly pursue the political agenda instead of to gain economic efficiency in the tactical choices due to which the profitability of the firms gets declines. The other view is that state-owned enterprises received bail out packages when facing financial difficulty (Shelfeir \& Vishny 1997; Blanchard \& Shleifer 2001). Many firms in the developing economies that are state-owned firms face less financial constraint as compared to other ownership structure firms due to the state financial bailout package (Lizal \& Svenjar 2002).

According to Naughton (1995), state-owned firms mostly pursue non-economic agenda and fails to compete the private sector firms. The empirical literature on the impact of state ownership on the earnings quality is still controversial and lacking. Most of the time, the managers of state-owned firms are under the influence of controlling party due to which they prefer to manipulate the current earnings of the firms to mask the poor performance and limits the disclosure of the information (Pongsaporant 2016; Shleifer \& Vishny 1997).

As far as the credibility and transparency of the financial reports are concerned it is still inconclusive and unclear that the managers of the state controlled firms would perform in the same manner as the other ownership structure (Wang \& Yung 2011). Eng and Mak (2003) argued that economic efficiency and profitability are not concerned to state-owned firms especially in the developing countries as they can easily resolve the issue of illiquidity, as state can provides them easy finances as compared to non-state owned firms. Najid and Rehman (2011) documented that state associated and interconnected companies in Malaysia shows a positive association to income manipulation. Shareholders have faith, that state can improve the company on the bases of impartiality and steadiness of the economy in any difficult circumstances. They further added that in difficult economic situation government bailout state-owned firms.

Rafique et al. (2017) explored the impact of Government ownership on discretionary accruals in (Australia, Malaysia and Pakistan) for the period 2011-2013. The research found that in Pakistan contrary to Malaysia and Australia the performance of state-owned enterprises are poor, so to mask the performance manager are engage in earnings manipulation through discretionary accruals. Based on these discussions, another hypothesis is as follow:

H3: State Ownership is negatively related with financial reporting quality (Positively associated with real earnings manipulation)

\section{FAMILY OWNERSHIP AND FINANCIAL REPORTING QUALITY}

Family- owned businesses are considered to be much more different from other forms of ownership in several way, one is because of their individual features they are expected to affect the resource allocation choices and incentive to deliver high (low) earnings quality (Lebreton-Miller \& Miller 2009). Secondly in family-owned firms members of extended family have an enormous stake in the company, so they have a great influence over senior management (Anderson \& Reeb 2003).

Shleifer and Vishny (1997) documented that two different perspectives have been reported in the previous studies on the relationship between families owned business and earnings quality. One is the entrenchment effect and the second is the alignment effect. Entrenchment effect supports the old-style aspect that family-owned businesses may take undue advantage by exploiting minority shareholders as most of the members on board of the company belongs to the family due to which the monitoring mechanism through board is very weak. Entrenchment effect creates 
information asymmetries between family dominant board members and other stake holders of the company (Anderson \& Reeb 2003). Hence family firms are considered to be less competent as the business is always headed and run by the family members and with the intention to passes the business to next peers often leads to damaging favoritism and the absence of professional management. This limits the overall ability of the firm to hire valuable and professional external managers outside the controlling family (Schulze et al. 2003). Fan and Wong (2006) argued that family members confines the accounting data to other shareholders. Mostly for their own personal benefit family owned firms manipulate the accounting data, therefore their finding confirmed that the quality of financial reports is very poor in family-owned firms.

Alignment effect argued that due to the majority of stake of family members in the company enforces the alliance of interest of both family members and other shareholders'. According to Chen et al. (2014), most of the board members on board of family firms are from family, so they have lower tendency to manipulate earnings. Alignment effect predicts that opportunistic behavior of mangers are less in family firms, so they are less engage in earnings manipulation. (Pongsaporamat 2016). Bona-Sanchez et al. (2011) on comparing the quality of financial reporting in family and non-family firms, concluded that the quality of accounting information are more higher in family firms than counterparts.

Ali et al. (2007) argued that regardless of the fact that family-owned firms disclosed less accounting information, still the quality of financial information are transparent and credible as compared to non-family owned businesses. Their research added that accounting data is not related to the chief executives compensation, therefore there is less motivation to manipulate earnings.

Wang (2006) suggested that founding family-owned are positively or negatively affecting the financial reporting quality is an empirical issue depending on the country specific characteristic and accordingly this study propose the following non- directional hypothesis:

H4: Family Ownership is associated with financial reporting quality.

\section{METHODOLOGY \\ SAMPLING AND DATA COLLECTION}

The study examined the data for the years 2008-2017. Due to different CG structure the financial sector is omitted from the final sample (Klein 2002; Davidson et al. 2005). In 2007 Pakistan made major progress in updating its accounting standard up to the international level (Financial Standards Report 2010). The study period is therefore from 2008 as most of the accounting standards (IFRS) in Pakistan have been implemented in 2007. According to Rehman and Shahzad (2014) and Ma et al (2015), choosing study period after change in accounting standards will bring consistency in the handling of accounting variables employed in the analysis. The data is extracted from the sample company's annual financial reports, respective websites and websites of financial information providers. The companies for which data was not available were excluded from the final sample, so for this paper sample size was limited to 150 companies.

\section{ROYCHOWDHURY MODEL (2006)}

Roychowdhury's (2006) model is used in this research to estimate the measure of financial reporting quality through real earnings manipulation. The model is widely popular in the earnings management and employed in latest studies (Cohen et al. 2011; Farooqi et al. 2014; Gunny 2010; Kim \& Park 2014; Mellado-Cid et al. 2018; Zang 2012). These measures are abnormal cash flow from operating activities (ABCFO) and abnormal discretionary expenses (ABDISX). The models are estimated cross-sectional Ordinary Least Squares (OLS) regression, on the industry-year basis. Equation (1) models abnormal cash flow from operations whereas, equation (2) models abnormal discretionary expenses.

$$
\begin{aligned}
& \frac{C F O_{i, t}}{A_{i, t-1}}=\alpha_{0}+\alpha_{1}\left(\frac{1}{A_{i, t-1}}\right)+\alpha_{2}\left(\frac{S_{i, t}}{A_{i, t-1}}\right)+\alpha_{3}\left(\frac{\Delta S_{i, t}}{A_{i, t-1}}\right)+\epsilon_{i, t} \\
& \frac{\operatorname{DISEXP}_{i, t}}{A_{i, t-1}}=\alpha_{0}+\alpha_{1}\left(\frac{1}{A_{i, t-1}}\right)+\alpha_{2}\left(\frac{S_{i, t-1}}{A_{i, t-1}}\right)+\epsilon_{i, t}
\end{aligned}
$$


where for firm ' $i$ ' in period 't' $\boldsymbol{C} \boldsymbol{F} \boldsymbol{O}_{i, t} \boldsymbol{r e p r e s e n t s ~ t h e ~ c u r r e n t ~ c a s h ~ f l o w ~ f r o m ~ o p e r a t i o n . ~} \boldsymbol{D} I \boldsymbol{S} \boldsymbol{E} \boldsymbol{X} \boldsymbol{P}_{\boldsymbol{i}, \boldsymbol{t}}$ represents the discretionary expenditure including those for selling and administrative expenses, advertising and research and development. $S_{i, t}$ represents the sale revenue. $\boldsymbol{\Delta} \boldsymbol{S}_{\boldsymbol{i}, \boldsymbol{t}}$ is the change in sale revenues of firm ' $i$ ' in year' $t$ '. $\boldsymbol{A}_{\boldsymbol{i}, \boldsymbol{t}-\mathbf{1}}$ represents the lagged value of the total assets.

The first model relates to the management offering discount or more favorable credit terms to accolade sales by declining margins for any additional sale. By doing so the firm earnings in the current period increase as the additional sales are booked. The net effect would be a lower CFO for the current period. Thus the residual obtained from the

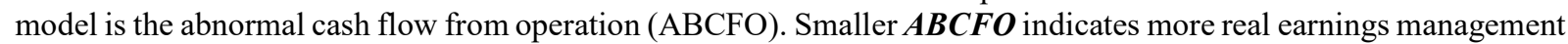
(Shayan-Nia et al. 2017). We multiply $\boldsymbol{A B C F O}$ by -1 so that high value represents higher earnings manipulation. The second model pertains simply to reducing discretionary expenses to upsurge the current period earnings. Therefore residuals (deviation from normal) obtained from the model are abnormal discretionary expenses (ABDISEXP). "Discretionary expenses of a company $i$ for year $t$, estimated as the sum of research and development expense, advertising expense and selling, general and administrative expenses". The expenses are considered as nil if not reported in the annual reports (Shayan-Nia, et al. 2017). We multiply $\boldsymbol{A B D I S E X P}$ by -1 so that higher value represents higher real earnings management. Following (Zang 2012; Cohen \&Zarowin 2010; Shayan-Nia et al. 2017; Mellado \& Saona 2018).

We use aggregate REM as a measure of real earnings manipulation to reduce the measuring bias by adding ABCFO and ABDISEX as both these measures have a similar directional association. Following Badertcher (2011) and Kaldonski et al. (2019) that higher ABCFO and ABDISEXP indicates higher levels of REM. The aggregate measure is calculated as $\boldsymbol{R E M}=\boldsymbol{A B C F O}+\boldsymbol{A B D I S E X P}$ (Cohen et al., 2011; Gunny, 2010).

\section{CONTROL VARIABLES}

The research uses different firm specific characteristics as control variables to reduce the omitted variables bias. The variables included are in line with the previous studies are size of firm, company growth, profitability, leverage, listing age and audit quality (Alzoubi 2016; Rafique et al. 2017; Chen et al. 2007) (Table describe the variables in detail).

\section{MODEL SPECIFICATION}

To test the hypotheses the study uses the research model used in the studies of Shayan-Nia et al. (2017) and Alzoubi (2016) with some modification to find the impact of ownership structure on REM in the Pakistani firms.

$$
\begin{aligned}
& A B C F O_{i, t}=\alpha_{0}+\beta_{1} M_{i, t}+\beta_{2} I_{i, t}+\beta_{3} S_{i, t}+\beta_{4} F_{i, t}+\beta_{5} \text { SIZE }_{i, t}+\beta_{6} G_{R O W T H}+\beta_{i, t} A G E_{i, t}+ \\
& \beta_{8} L E V_{i, t}+\beta_{9} B I G 4_{i, t}+\beta_{10} R O A_{i, t}+\beta_{11} I N D U S D U M_{i, t}+\beta_{12} \text { YEARDUM }_{i, t}+\varepsilon_{i, t}
\end{aligned}
$$

ABDISEXP $P_{i, t}=\alpha_{0}+\beta_{1} M O_{i, t}+\beta_{2} I_{i, t}+\beta_{3} S O_{i, t}+\beta_{4} F_{i, t}+\beta_{5} \operatorname{SIZE}_{i, t}+\beta_{6}$ GROWTH $_{i, t}+\beta_{7} A G E_{i, t}+$ $\beta_{8} L E V_{i, t}+\beta_{9} B I G 4_{i, t}+\beta_{10} R O A_{i, t}+\beta_{11} I N D U S D U M_{i, t}+\beta_{12} Y E A R D U M_{i, t}+\varepsilon_{i, t}$

$R E M_{i, t}=\alpha_{0}+\beta_{1} M O_{i, t}+\beta_{2} I O_{i, t}+\beta_{3} S O_{i, t}+\beta_{4} F O_{i, t}+\beta_{5} S I Z E_{i, t}+\beta_{6} G R O W T H_{i, t}+\beta_{7} A G E_{i, t}+$ $\beta_{8} L E V_{i, t}+\beta_{9} B I G 4_{i, t}+\beta_{10} R O A_{i, t}+\beta_{11} I N D U S D U M_{i, t}+\beta_{12} Y E A R D U M_{i, t}+\varepsilon_{i, t}$

Following Table I represents the description and measurement of the variables of the study. The subscript ' $i$ ' denotes firm, and ' $t$ ' denotes the fiscal year, where $\mathrm{t}=1,2,3 \ldots \ldots .10$. All equations include year and industry fixed effect. 
TABLE 1. Definition and Measurement of Variables

\begin{tabular}{|c|c|c|c|c|}
\hline Variables & Label & $\begin{array}{l}\text { Nature of } \\
\text { Variable }\end{array}$ & Description & Reference \\
\hline \multicolumn{5}{|l|}{$\begin{array}{l}\text { Dependent } \\
\text { Variable }\end{array}$} \\
\hline $\begin{array}{l}\text { Real } \\
\text { Earnings } \\
\text { Manipulation }\end{array}$ & $\begin{array}{c}\text { ABCFO, } \\
\text { ABDISEXP,REM }\end{array}$ & Numerical & Roychowdhury (2006) model & $\begin{array}{c}\text { Farooqi et al. (2014), Mellado-Cid et } \\
\text { al. (2018) }\end{array}$ \\
\hline \multicolumn{5}{|l|}{$\begin{array}{l}\text { Independent } \\
\text { Variables }\end{array}$} \\
\hline $\begin{array}{l}\text { Managerial } \\
\text { Ownership }\end{array}$ & MO & Numerical & $\begin{array}{l}\text { Percentage of equity owned by } \\
\text { non-executive directors on } \\
\text { board/Total share issued }\end{array}$ & Habbash (2010), Alves (2012) \\
\hline $\begin{array}{l}\text { Institutional } \\
\text { Ownership }\end{array}$ & IO & Numerical & $\begin{array}{c}\text { Percentage of equity owned by } \\
\text { financial institutions/Total share } \\
\text { issued }\end{array}$ & $\begin{array}{l}\text { Gonzalez \& Garcia-Meca (2014), } \\
\text { Alzoubi (2016) }\end{array}$ \\
\hline $\begin{array}{l}\text { State } \\
\text { Ownership }\end{array}$ & $\mathrm{SO}$ & Numerical & $\begin{array}{l}\text { Percentage of equity owned by } \\
\text { Government/Total share issued }\end{array}$ & $\begin{array}{l}\text { Yasser et al. (2017), Udin et al. } \\
\text { (2017) }\end{array}$ \\
\hline $\begin{array}{l}\text { Family } \\
\text { Ownership }\end{array}$ & FO & Categorical & $\begin{array}{c}\text { Coded } 1 \text { if family members } \\
\text { Majority seats in board; } \\
\text { otherwise }=0 .\end{array}$ & Shahzad et al.(2017) \\
\hline \multicolumn{5}{|l|}{$\begin{array}{l}\text { Control } \\
\text { Variables } \\
\end{array}$} \\
\hline Firm Size & SIZE & Numerical & f total assets & $\begin{array}{l}\text { Alzoubi (2016), Gonzalez \& } \\
\text { Garcia-Meca (2014) }\end{array}$ \\
\hline Firm Growth & GROWTH & $\mathrm{Nu}$ & Asset growth rate & Alzoubi (2016) \\
\hline Firm Age & AGE & Numerical & $\begin{array}{l}\text { Number of years firm listed on } \\
\text { PSX }\end{array}$ & $\begin{array}{l}\text { Rafique et al (2017) Shahzad et } \\
\text { al.(2017) }\end{array}$ \\
\hline Leverage & LEV & Numerical & Ratio of total debt to total assets & $\begin{array}{l}\text { Rafique et al.(2017), Nazir \& Afza } \\
\text { (2018) }\end{array}$ \\
\hline $\begin{array}{l}\text { Audit } \\
\text { Quality }\end{array}$ & & Categorical & $\begin{array}{c}\text { Dummy variable } 1 \text { if the auditor is } \\
\text { a Big } 4 \text { and } 0 \text { otherwise }\end{array}$ & $\begin{array}{l}\text { Abid et al. (2018), Shahzad et al. } \\
\text { (2017) }\end{array}$ \\
\hline Profitability & ROA & Numerical & Net income/Total assets & Rafique et al. (2017) \\
\hline
\end{tabular}

\section{DATA ANALYSIS AND RESULTS}

\section{DESCRIPTIVE ANALYSIS}

Table 2, demonstrate the summary of variables that are included in the model. The average value of REM is -0.18 that indicates that companies in Pakistan manipulate earnings downwards through real activities. The average value of ABCFO and ABDISEXP are -0.08 and -0.09 indicating income-decreasing earnings manipulation. Murya (2010) argued that companies use income decreasing earnings manipulation when the forecasted earnings are inferior to premanaged earnings and later on do the adjustment in the future financial reports. 
The average value of managerial ownership is $23.59 \%$ and maximum value of $98.7 \%$ which indicates that manger holds a large percentage of shares in some firms in Pakistan in period from 2008-2017. Institutional ownership indicates that the numbers of shares held by national investment trust, financial institutions and Investment Corporation of Pakistan have the mean value of $48.33 \%$. The mean value of managerial and institutional ownership represents concentrated ownership structure in Pakistan. The mean value of institutional ownership indicates that financial institutions have very active role in companies' strategic decisions in Pakistan. The average value of state ownership is notably low and is equal to 3.5 percent. $90 \%$ and $0 \%$ are the maximum and minimum value of Government shares in public limited companies respectively. The maximum value of $90 \%$ shows that Government and Government officials holds major shares in public limited companies in Pakistan.

TABLE 2. Descriptive Statistics

\begin{tabular}{lllll}
\hline Variables & Mean. & Std. dev. & Min. & Max. \\
\hline ABCFO & -0.08 & 0.04 & -0.58 & 0.06 \\
ABDISEXP & -0.09 & 0.03 & -0.52 & -0.01 \\
REM & -0.18 & 0.08 & -1.11 & 0.01 \\
MO & 0.23 & 0.27 & 0 & 0.98 \\
IO & 0.48 & 0.31 & 0 & 0.96 \\
SO & 0.03 & 0.14 & 0 & 0.90 \\
SIZE & 8.83 & 1.48 & 3.89 & 13.34 \\
GROWTH & 0.11 & 0.38 & -0.89 & 11.22 \\
AGE & 29.20 & 12.04 & 7.00 & 56.00 \\
LEV & 0.64 & 0.42 & 0 & 10.11 \\
ROA & 0.04 & 0.12 & -1.28 & 1.10 \\
\hline
\end{tabular}

The average size of the firm is 8.83 , having maximum value of 13.34 . The growth rate varies between 0.11 to -0.89 during the period 2008-2017. The mean value of the firm age included in the sample is 29 years with standard deviation of 12 suggesting that majority of the firm are at the mature stage in their respective industries. Leverage value lies between 0 and 10.11 with an average value of 0.64 indicating that the leverage is quite high in the Pakistani firm. The mean value of profitability (ROA) is 0.0484 indicates that on average our sample is profitable.

\section{CORRELATION MATRIX}

Table 3 illustrate the simple correlation matrix between the variables used in the study. The table indicates that there is negative and significant relationship between institutional ownership and real earnings manipulation while state ownership and family ownership are positively and significantly related to the real earnings manipulation. Table 3, indicate no severe multi-collinearity issue as none of the correlation between independent variables were highly correlated ( $>0.90)$ to establish multicollinearity issues (Gujrati \& Porter 2009).

TABLE 3. Spearman Correlation Matrix

\begin{tabular}{|c|c|c|c|c|c|c|c|c|c|c|c|}
\hline & REM & MO & $\mathrm{IO}$ & $\mathrm{SO}$ & $\mathrm{FO}$ & SIZE & GROWTH & AGE & LEV & BIG 4 & ROA \\
\hline REM & 1 & & & & & & & & & & \\
\hline MO & -0.01 & 1 & & & & & & & & & \\
\hline $\mathrm{IO}$ & $-0.10 * * *$ & $-0.429 * * *$ & 1 & & & & & & & & \\
\hline $\mathrm{SO}$ & $0.099 * * *$ & $0.151^{* * *}$ & $-0.221 * * *$ & 1 & & & & & & & \\
\hline FO & $0.113 * * *$ & $0.482 * * *$ & $-0.434 * * *$ & $-0.287 * * *$ & 1 & & & & & & \\
\hline SIZE & -0.036 & $-0.281 * * *$ & $0.093 * * *$ & $0.410 * * *$ & $\begin{array}{c}- \\
0.357^{* * *}\end{array}$ & 1 & & & & & \\
\hline GROWTH & $-0.39 * * *$ & -0.027 & 0.002 & $0.060 * *$ & -0.044 & $0.106^{* * *}$ & 1 & & & & \\
\hline
\end{tabular}




\begin{tabular}{|c|c|c|c|c|c|c|c|c|c|c|c|}
\hline AGE & $-0.13 * * *$ & 0.021 & $-0.058 * *$ & $0.047^{*}$ & $0.090 * * *$ & 0.008 & $0.062 * *$ & 1 & & & \\
\hline LEV & $0.146^{* * *}$ & $0.109^{* * *}$ & $-0.127^{* * *}$ & -0.035 & $0.084 * * *$ & $\stackrel{-}{-} 0.076^{* * *}$ & $-0.061^{* *}$ & $0.072 * * *$ & 1 & & \\
\hline BIG 4 & $0.153 * * *$ & $-0.181 * * *$ & $0.169 * * *$ & $0.173 * * *$ & $-0.41 * * *$ & $0.294 * * *$ & $0.045^{*}$ & $-0.11 * * *$ & $-0.24 * * *$ & 1 & \\
\hline ROA & $-0.28 * * *$ & $-0.097 * * *$ & $0.131 * *$ & $0.077 * * *$ & $-0.16 * * *$ & $0.089 * * *$ & $0.103 * * *$ & $-0.045^{*}$ & $-0.41 * * *$ & $0.223 * * *$ & 1 \\
\hline
\end{tabular}

*** Significant at 1\%; **; Significant at 5\%; * Significant at 10\%.

TABLE 4.Checking of Multicollinearity

\begin{tabular}{lll}
\hline Variable & VIF & $1 /$ VIF \\
\hline IO & 3.05 & 0.3278 \\
MO & 2.71 & 0.3684 \\
FO & 1.73 & 0.5766 \\
SO & 1.52 & 0.6588 \\
LEV & 1.27 & 0.7903 \\
ROA & 1.26 & 0.7949 \\
AGE & 1.03 & 0.9745 \\
\hline Mean VIF & 1.73 & \\
\hline
\end{tabular}

The variance inflation factor (Table 4) indicates no multicollinearity. The average value of VIF (1.73) remain below a value of 10, which has been recommended as the maximum level of VIF (Hair et al. 2006).

TABLE 5.Autocorrelation test

\begin{tabular}{llll}
\hline & Model (3) & Model (4) & Model (5) \\
\hline F-Statistics & 11.809 & 90.176 & 27.106 \\
Prob $>$ F & 0.0008 & 0.000 & 0.000 \\
\hline
\end{tabular}

Table 5 illustrate the results of the Wooldridge test to investigate whether there is any issue of auto correlation exist in the research models. The $\mathrm{p}$ value of all three models suggest the issue of autocorrelation.

TABLE 6. Heteroskedasticity test

\begin{tabular}{llll}
\hline & Model (3) & Model (4) & Model (5) \\
\hline Chi2 & 68751.92 & 7654.21 & 8534.50 \\
Prob $>$ Chi2 & 0.000 & 0.000 & 0.000 \\
\hline
\end{tabular}

Table 6 reports the results of Wald test to investigate whether there is any issue of heteroskedasticity exist in the research models. The $\mathrm{p}$ value of all three models suggest the presence of heteroskedasticity.

TABLE 7. Pesaran test

\begin{tabular}{llll}
\hline & Model (3) & Model (4) & Model (5) \\
\hline Pesaran test value & 26.730 & 38.028 & 30.7111 \\
Prob & 0.000 & 0.000 & 0.000 \\
\hline
\end{tabular}

Table 7 reports the results of the Pesaran test of cross-sectional independence (also called contemporaneous correlation) to investigate whether there is any problem of cross sectional dependence exist in the research models. The $\mathrm{p}$ value of all three models suggest the presence of cross sectional dependence.

For the appropriateness of the model we employ Wooldridge test for examining the issue of autocorrelation in the models the result of the test indicates the existence of auto correlation in the model. We further examines the issue of heteroskedasticity and cross sectional dependence in the econometric model by employing modified Wald for heteroskedasticity and Pesaran test of cross section dependence. The results confirmed the problem of heteroscedasticity and cross section dependence (contemporaneous correlation). Feasible generalized least square (FGLS) econometric technique is applied to the regression model to resolve the problems. 


\section{REGRESSION RESULTS}

The Table 8 documents the effects of feasible generalized least square (FGLS) method for all three models by taking abnormal cash flow from operation, abnormal discretionary expenses and aggregate REM as proxy of financial reporting quality as dependent variable. The result suggest that, managerial ownership negatively and significantly affect the abnormal cash flow from operation, abnormal discretionary expenses and REM_aggregate which lent support to the H1. (Lower REM indicates higher FRQ). This advocates that mangers who possess a substantial amount of share in the equity of firm would reduce REM and enhance financial reporting quality. Several previous studies (Teshima \& Shuto 2008; Alves 2012; Alzoubi 2016) also found similar result and supports the alignment hypothesis.

The proportion of institutional ownership indicates negative sign but statistically insignificant. However the negative sign indicates that institutional ownership is associated with better monitoring of management activities to reduce or limit the opportunistic behavior and reducing the real earnings manipulation. The positive significant relationship between state ownership and REM (all three measures) indicates that that there is more bureaucratic interference in the state-owned enterprise which result poor performance. Managers of the state owned firms mask the firm poor performance and limits the disclosure for the benefit of controlling parties and reduces the quality of financial reporting, the result is consistent with the studies of (Wang \& Young 2001; Najid \& Abdul Rehman 2011).

TABLE 8. Regression Results (FGLS Results)

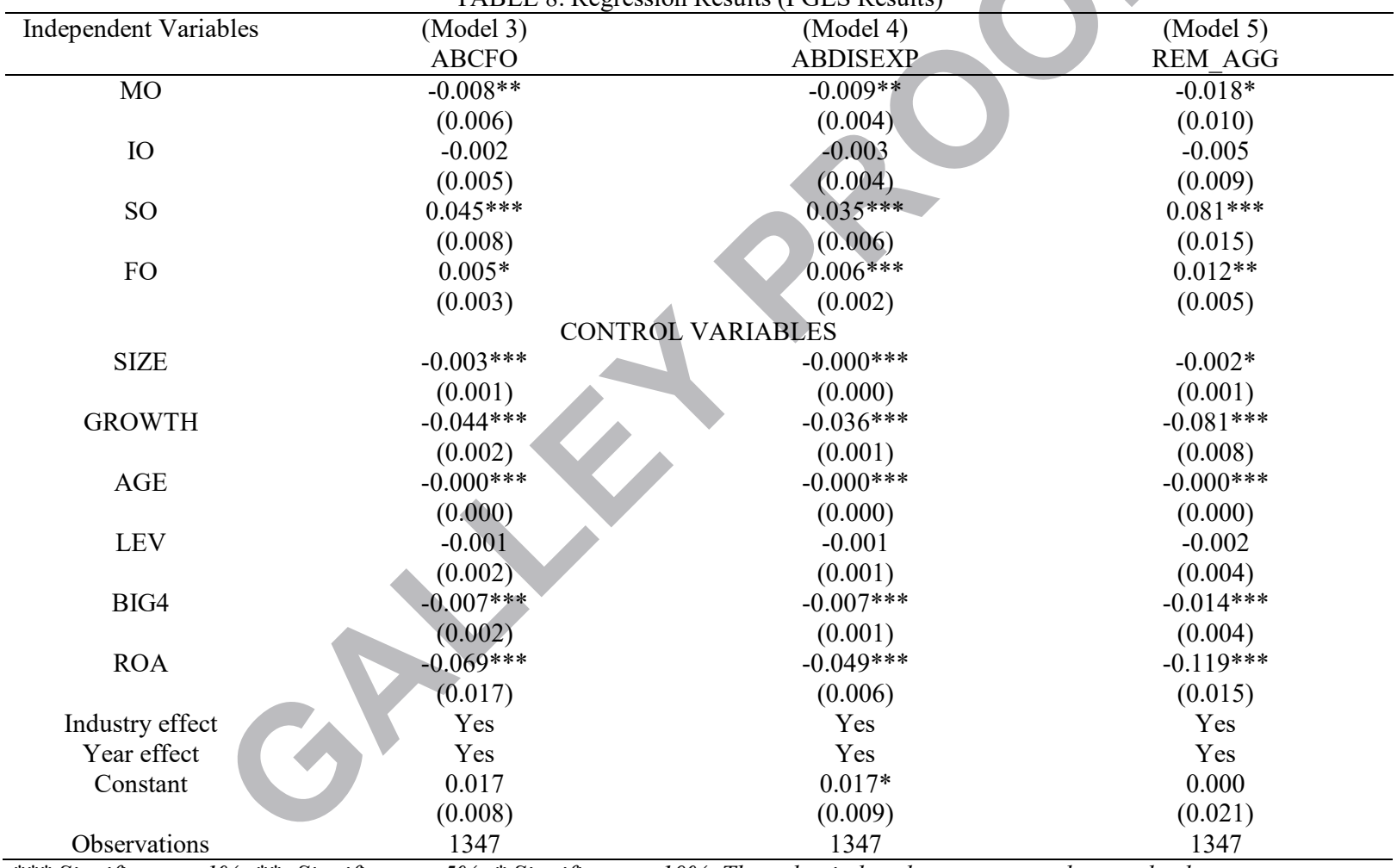

*** Significant at 1\%; **; Significant at 5\%; * Significant at 10\%. The value in bracket represents the standard errors.

According to the family ownership variable, the result shows that family ownership positive significantly affect earnings manipulation (all three measures). This indicates that family ownership reports high REM in the Pakistani firms. The result of the hypothesis confirm the entrenchment effect. In Pakistan family members hold key position on the company board due to which the monitoring mechanism through board is weak. As most of controlling family owners are in charge of accounting policies and flow of information to public, they are perceived to have incentive for opportunistic earnings manipulation for private benefit at the expense of minority shareholders (Fan \& Wong, 2002). The result is in consistence with previous studies (Andreson \& Reeb 2003; Fan \& Wong 2002). Size, growth, age, BIG4 and ROA variables are negatively significant related to REM. These finding offer evidence that growth and profitable companies, firm age and audit quality are less engage in earnings manipulation and enhance financial reporting quality. These result also have been reported in other studies like Bedard, et al. 2004; Jaggi et al. 2001 and 
Gul et al. 2009). However, leverage shows a negative insignificant association with earnings manipulation, whereas the result documents that larger firms shows a negative and significant relationship with earnings manipulation.

\section{ROBUSTNESS RESULTS}

To study the robustness of our results, we estimated all three models by using panel corrected standard error (PCSE) econometric technique. There exist in a literature that in the presence of cross sectional dependence in the model the best technique to use is PCSE. Shahzad et al. (2017) and Konadu (2017) argued that in the presence of cross sectional dependence in the model best estimation strategy is to use panel corrected standard error (PCSE). As the Pesaran's test of cross sectional independence indicate the cross sectional dependence/ contemporaneous correlation in the model, the best suited econometric strategy is to employ PCSE technique. Table 9 presents the results of the panel standard corrected error method and indicates that results are similar to which are reported in Table 8.

TABLE 9. Regression Results (PCSE Results)

\begin{tabular}{|c|c|c|c|}
\hline Independent Variables & $\begin{array}{l}\text { (Model 3) } \\
\text { ABCFO }\end{array}$ & $\begin{array}{l}\text { (Model 4) } \\
\text { ABDISEXP }\end{array}$ & $\begin{array}{l}\text { (Model 5) } \\
\text { REM AGG }\end{array}$ \\
\hline \multirow[t]{2}{*}{$\mathrm{MO}$} & $-0.008 * * *$ & $-0.009 * * *$ & $-0.018 * * *$ \\
\hline & $(0.003)$ & $(0.002)$ & $(0.005)$ \\
\hline \multirow[t]{2}{*}{ IO } & -0.002 & -0.003 & -0.005 \\
\hline & $(0.004)$ & $(0.002)$ & $(0.006)$ \\
\hline \multirow[t]{2}{*}{ SO } & $0.045 * * *$ & $0.035 * * *$ & $0.080 * * *$ \\
\hline & $(0.006)$ & $(0.004)$ & (0.009) \\
\hline \multirow[t]{2}{*}{ FO } & $0.005 * * *$ & $0.006 * * *$ & $0.012 * *$ \\
\hline & $(0.001)$ & $(0.001)$ & $(0.002)$ \\
\hline \multirow{2}{*}{ SIZE } & $-0.003 * * *$ & $-0.000^{* * *}$ & $-0.002 * * *$ \\
\hline & $(0.001)$ & $(0.001)$ & $(0.001)$ \\
\hline \multirow[t]{2}{*}{ GROWTH } & $-0.044 * * *$ & $-0.044 * * *$ & $-0.081 * * *$ \\
\hline & $(0.003)$ & $(0.003)$ & $(0.005)$ \\
\hline \multirow[t]{2}{*}{ AGE } & $-0.000 * * *$ & $-0.000 * * *$ & $-0.000 * * *$ \\
\hline & $(0.000)$ & $(0.000)$ & $(0.000)$ \\
\hline \multirow[t]{2}{*}{ LEV } & -0.001 & -0.001 & -0.002 \\
\hline & $(0.002)$ & $(0.002)$ & $(0.003)$ \\
\hline \multirow[t]{2}{*}{ BIG4 } & $-0.007 * * *$ & $-0.007 * * *$ & $-0.014 * * *$ \\
\hline & $(0.002)$ & $(0.001)$ & $(0.003)$ \\
\hline \multirow[t]{2}{*}{ ROA } & $-0.069^{* *}$ & $-0.049 * * *$ & $-0.119 * * *$ \\
\hline & $(0.008)$ & $(0.007)$ & $(0.016)$ \\
\hline Industry effect & Yes & Yes & Yes \\
\hline Year effect & Yes & Yes & Yes \\
\hline \multirow[t]{2}{*}{ Constant } & 0.017 & $0.017 *$ & 0.000 \\
\hline & $(0.019)$ & $(0.010)$ & $(0.026)$ \\
\hline Observations & 1347 & 1347 & 1347 \\
\hline R-squared & 0.482 & 0.511 & 0.499 \\
\hline
\end{tabular}

*** Significant at 1\%; **; Significant at 5\%; * Significant at 10\%. The value in bracket represents the standard errors

\section{CONCLUSION}

In this research we have empirically studied the effect of ownership structure on financial reporting quality measured through real earnings manipulation. We have examined the effect of managerial ownership, institutional ownership, state ownership and family ownership on REM measured through abnormal cash flow from operation, abnormal discretionary expenses and the aggregate measure. The empirical finding suggest that ownership structure is an imperative monitoring tool to control earnings manipulation (through REM) in the Pakistani firms. Precisely the empirical result suggest that managerial ownership limits the income manipulation behavior of the management and enhances the financial reporting quality. The empirical result supports the alignment hypothesis, which suggest that if managers owns a substantial equity in firms they have fewer incentives to manipulate earnings for their self-interest.

Result also suggest that institutional investors also plays a vigorous part in curbing the opportunistic behavior of managers in manipulating earnings. The relation between institutional ownership and earnings manipulation supports 
efficient monitoring hypothesis in the Pakistani market which suggest that institutions being the large shareholders monitors the management behavior and curtails the income manipulation and enhances the financial reporting quality. Moreover, the result also reveal that state ownership and family ownership are positively associated to the real earnings manipulation and lowers the financial reporting quality. The result in case of state ownership shows that in stateowned firms the quality of governance and monitoring is very low in Pakistan. The result indicate that family owned firms are engage in income manipulation practices through real earnings manipulation. The result overall supports the entrenchment effect of the agency theory.

This research contributed to the empirical literature on the association between ownership structures on earnings manipulation proxied by REM through Rowchadhry model (2006). The research extended the literature on financial reporting quality through real earnings management in Pakistan. Second, the finding indicates that on average managerial ownership and institutional ownership are the best monitoring mechanism that can restricts managers from earnings manipulation and enhances financial reporting quality.

The finding of this study is useful for the investors to understand the impact of ownership on earnings quality. In sum, the result of the paper highlights the importance of ownership structure in income manipulation practices in Pakistani listed firms. The financial reporting quality through real earnings manipulation is not associated with managerial ownership However, state ownership and family ownership firms are engage in income manipulation through real earnings manipulation.

This study also has some limitations hence providing directions for further research. A significant ownership variables like Government ownership and foreign ownership were not examined in the current study. Based on the result of this study, further research should expand the variables used to measure the effect on the financial reporting quality not only limited to the ownership structure but also include other corporate governance variables. In addition, it is recommended to use different financial reporting quality measures for more concrete results, not limited to the earnings manipulation.

\section{ACKNOWLEDGEMENT}

The authors are grateful to the anonymous referees of the journal for their extremely useful suggestions to improve the quality of the article.

\section{REFERENCES}

Abdullah, S. 1999. The role of corporate governance and ownership structure on accounting earnings quality. Unpublished PhD Dissertation. University Utara Malaysia.

Adebiyi, W.K., \& Olowookere, J.K. 2016. Ownership Structure and the Quality of Financial Reporting: Evidence from Nigerian Deposit Money Banks. International Journal of Economics, Commerce and Management 4(1): 541-552.

Abid, A., Shafiq, M. \& Anwar UL Haq. 2018. Do BIG4 Auditors always provide higher Audit Quality? Evidence from Pakistan. International Journal of Financial Studies 6(58): 1-22.

Affan, W. M., Rosidi, S. E., \& Purwanti, M. 2017. The effect of Ownership Structure on the Quality of financial reporting of manufacturing companies listed in IDX during the period of 2011-2013. Imperial Journal of Interdisciplinary Research 3 (7): 165-174.

Ali, A., Chen, T.Y. \& Radhakrishnan, S. 2007. Corporate disclosures by family firms. Journal of Accounting and Economics 44 (1): 238-286.

Alves, S. 2012. Ownership Structure and Earnings Management: Evidence from Portugal. Australian Accounting Business and Finance 6(1): 57-74

Alzoubi, E.S.S. 2016. Ownership structure and earnings management: evidence from Jordan. International Journal of Accounting \& Information Management 24(2): 135-161

Anderson, R.C., \& Reeb, D.M. 2003. Founding-family ownership and firm performance: evidence from the S\&P 500. The Journal of Finance 58(3): 1301-1327

Arshad, H., \& Javid, Y. A. 2014. Does inside ownership matters in financial decisions and firm performance: Evidence from manufacturing sector of Pakistan (PIDE Working Paper No. 107)

Ayadi, M.W., \& Boujelbene, Y 2015. Internal governance mechanism and value relevance of accounting earnings: An empirical study in French context. International Journal of Managerial and Financial Accounting 7(1):122. 
Ayadi, W.M. 2014. The relationship between ownership structure and earnings quality in the French context. International Journal of Accounting and Economics Studies 2(2):80-87.

Aygun, M., Suleyman, I., \& Sayim, M. 2014. The Effects of Corporate Ownership Structure and Board Size on Earnings Management: Evidence from Turkey. International Journal of Business and Management 9(12):123132.

Badertscher, B.A., 2011. Overvaluation and the Choice of Alternative Earnings Management Mechanisms. The Accounting Review 86 (5):1491-1518.

Balasam, S., Bartov, E., \& Marquard, C. 2000. Accrual management, Investor sophistication, and equity valuation: Evidence from 10Q filing. Working paper.

Bedard, J., Chtourou, S.M. \& Courteau, L. 2004. The effect of audit committee expertise, independence, and activity on aggressive earnings management. Auditing: A Journal of Practice \& Theory 23(2):13-35.

Blanchard, O., \& Shleifer, A. 2001. Federalism without political centralization: China versus Russia. Special Issue, IMF staff papers 48:171-179.

Bona-Sanchez, C., Aleman, P.J \& Santana-Martin, D. 2011. Defence measures and earnings management in an owner dominant context. Journal of Business Finance and Accounting 38(7-8):765-793.

Bushee, B. 1998. Institutional investors, long-term investment, and earnings management. Working Paper, Harvard University.

Bushee, B. 2001. Do Institutional Investors Prefer Near-term Earnings Over Long-run Value? Contemporary Accounting Research 18:207-246.

Chen, K.Y., Elder, R.J. \& Hsieh, Y.M. 2007. Corporate governance and earnings management: The implications of corporate governance best-practice principles for Taiwanese listed companies. Journal of Contemporary Accounting \& Economics 3 (2): 73-105.

Chen, S., Chen, X., \& Cheng, Q. 2014. Conservatism and Equity Ownership of the Founding Family. European Accounting Review 23(3): 403-430.

Cheng, M., Dhaliwal, D., \& Zhang, Y. 2013. Does investment efficiency improve after the disclosure of material weaknesses in internal control over financial reporting? Journal of Accounting and Economics 56(1):1-18.

Man, C \& Wang 2013. Corporate governance and earnings management: A survey of literature. The journal of Applied Business Research 29(2): 391-418.

Chung, R., Firth, M., \& Kim, J. (2002). Institutional monitoring and opportunistic earnings management. Journal of Corporate Finance 81(1): 29-48.

Chung, R., Firth, M., \& Kim, J. 2005. Earnings Management, Surplus Free Cash flow and External Monitoring. Journal of Business Research 58(6):766-776

Claessens, S., \& Fan, J. 2002. Corporate governance in Asia: A survey. International Review of Finance, 3:71-103

Cohen, D. A., Pandit, S., Wasley, C. E., \& Zach, T. 2011. Measuring real activity management. SSRN Working Paper. Retrieved from http://ssrn.com/abstract=1792639.

Cohen, D.A., \& Zarowin, P. 2010. Accrual-based and real earnings management activities around seasoned equity offerings. Journal of Accounting and Economics 50 (1): 2-19.

Daily, C. M., Dalton, D. R., \& Cannella, A. C. 2003. Corporate Governance: Decades of dialogue and data. Academy of Management Review 28:371-382.

Davidson, R., Goodwin-Stewart, J. \& Kent, P. 2005. Internal governance structures and earnings management. Journal of Accounting \& Finance 45(2): 241-267.

Dechow, P., Ge, W., \& Schrand, C. 2010. Understanding earnings quality: A review of the proxies, their determinants and their consequences. Journal of Accounting and Economics, 50 (2): 344-401.

Eng, L. L., \& Mak, Y. T. 2003. Corporate governance and voluntary disclosure. Journal of Accounting and Public Policy 22: 325-345.

Fama, E. F., \& Jensen, M. C. 1983. Separation of ownership and control. Journal of Law and Economics 301-325.

Fama, E.F. (1980). Agency Problems and the Theory of the Firm. The Journal of Political Economy, 88(2):288-307.

Fan, J.P. \& Wong, T.J. 2002. Corporate ownership structure and the informativeness of accounting earnings in East Asia. Journal of Accounting and Economics 33(3): 401-425.

Farooqi, J., Harris, O., \& Ngo, T. 2014. Corporate diversification, real activities manipulation, and firm value. Journal of Multinational Financial Management 27:130-151.

Farouk,A.M. \& Bashir, M.N 2017. Ownership Structure and earnings management of listed conglomerates in Nigeria. India Pacific Journal of Accounting and Finance 1 (4): 42-45.

Francis, J., Lafond, R., Oisson, P., \& Schipper, K. 2004. Cost of equity and earning attributes. The Accounting Review, 79(4): 967-1010. 
Gaio, C. 2010. The relative importance of firm and country characteristics for earnings quality around the World. Euro. Accounting Review 19 (4): 693-738.

González, J.S. \& García-Meca, E. 2014. Does corporate governance influence earnings management in Latin American markets? Journal of Business Ethics, 121(3): 419-440.

Graham, J. R., Harvey, C. R., \& Rajgopal, S. 2005. The economic implications of corporate financial reporting. Journal of Accounting and Economics 40(1-3): 3-73.

Gujarati, D.N \& Porter, D. 2009. Basic Econometrics $5^{\text {th }}$ edition, Boston: McGraw-Hill.

Gul, F.A., Fung, S.Y.K. \& Jaggi, B. 2009. Earnings quality: Some evidence on the role of auditor tenure and auditors' industry expertise. Journal of Accounting and Economics 47 (3):265-287.

Gunny, K. A. 2010. The Relation between Earnings Management Using Real Activities Manipulation and Future Performance: Evidence from Meeting Earnings Benchmarks. Contemporary Accounting Research 27(3): 855888.

Habbash, M. 2010. The Effectiveness of Corporate Governance and External Audit on constraining Earnings Management Practices in The UK. PhD Thesis, Durham University, UK.

Hair, J. F., Black, B., Babin, B., Anderson, R. E., \& Tatham, R. L. 2006. Multivariate Data Analysis (6th ed.). New Jersey: Pearson.

Hashim, A., \& Devi, S. 2008. Board characteristics, Ownership Structure and Earnings Quality: Malaysian Evidence. Research in Accounting in Emerging Economies 8: 97-123.

Healy, P., \&Palepu, K. 2001. Information asymmetry, corporate disclosure and the capital markets: A review of the empirical disclosure literature. Journal of Accounting and Economics 31: 405-440.

Healy, P.M \& Wahlen J. M. 1999. A Review of the Earnings Management Literature and Its Implications for Standard Setting. Accounting Horizons 13 (4): 365-383.

Herrmann, D., Tatsuo, I., \& Wayne, B.T 2003. The Sale of Assets to Manage Earnings in Japan. Journal of Accounting Research 41: 89-108

Jackson, S. B., \& W.E. Wilcox. 2000. Do managers grant sales price reductions to avoid losses and declines in earnings and sales? Quarterly Journal of Business and Economics 39; 3.

Jaggi, B., Leung, S. \& Gul, F. 2009. Family control, board independence and earnings management: Evidence based on Hong Kong firms. Journal of Accounting and Public Policy 28 (4):281-300

Jensen, M. C. \& Meckling, W. H. 1976. Theory of the Firm: Managerial Behavior, Agency Costs and Ownership Structure. Journal of Financial Economics 3(4): 305-360.

Jonas, G. \& Blanchet, J. 2000. Assessing Quality of Financial Reporting. Accounting Horizons, 14(3): 353-363.

Kałdoński, M., Jewartowski, T \& Mizerka, J. 2019.Capital market pressure, real earnings management, and institutional ownership stability - Evidence from Poland. International Review of Financial Analysis 1-53.

Kazemian, S. \& Sanusi,M.Z 2015. Earnings Management and Ownership Structure. Procedia Economics and Finance. 31: 618-624.

Kim, J. \&Park, M. 2014. Real activities manipulation and auditors client retention decisions", The Accounting Review 89 (1): 367-401

Kirschenheiter, M., \& Melumad,N. 2004. Earnings' Quality and Smoothing. Available at: http:// SSRN.com.

Klein, A. 2002. Audit committee, board of director characteristics, and earnings management. Journal of Accounting and Economics 33(3): 375-400

Konadu, R. 2017. Corporate environmental performance and corporate financial performance: Empirical evidence from UK. PhD dissertation. Bournemouth University, UK.

Latif, A. \& Abdullah, F. 2015. The effectiveness of corporate governance in constraining earnings management in Pakistan. The Lahore journal of Economics, 20: 135-155.

Lebreton-Miller,I., \& Miller, D. 2009. Agency vs. Stewardship in Public Family Firms: A Social Embeddedness Reconciliation. Entrepreneurship Theory \& Practice 33(6): 1169-1191.

Lins, K.V., \& Warnock, F.E. 2004. Corporate Governance and the Shareholder Base. International Finance Discussion Papers, 816.

Liu, J., \& Tsai, C.C. 2015. Board Member Characteristics and Ownership Structure Impacts on Real Earnings Management: Evidence from Taiwan. Accounting and Finance Research 4(4): 86-96.

Lizal, L., \& Svejnar, J 2002. Investment, credit rationing, and the soft budget constraint: evidence from Czech panel data. The Review of Economics and Statistics 84(2): 353-370

Ma. L., Ma, S., \& Tian, G. 2015. Corporate opacity and cost of debt for family firms. European Accounting Review, $1-33$. 
Mellado, C \& Saona, P. 2018. Real Earnings Management and Corporate Governance: A Study for Latin America Available at SSRN: https://ssrn.com/abstract=3222094 or http://dx.doi.org/10.2139/ssrn.3222094.

Murya, H. 2010. The effectiveness of corporate governance and external audit on constraining earnings management practice in the UK. Durham, NC: Durham University.

Mellado-Cid, C., Jory, S. R., \& Ngo, T. N. 2018. Real activities manipulation and firm valuation. Review of Quantitative Finance and Accounting 50(4): 1201-1226.

Najid, N., \& Rahman, A. 2011. Government ownership and performance of Malaysian government linked companies. International Research Journal of Finance and Economics: 1-19.

Naughton, B. 1995. Growing Out of The Plan: Chinese Economic Reform, 1978-1993. New York: Cambridge University Press.

Nazir, S.M., \& Afza, T. 2018. Impact of corporate governance on discretionary earnings management: A case of Pakistani firms. Pakistan Economic and Social Review 56(1): 157-184.

Obigbemi, I. F. 2017. Ownership Structure and Earnings Management Practices of Nigerian Companies. Journal of Internet Banking and Commerce 22(S8): 2-8.

Ogbonnaya, A.K., Chidiebere Ekwe, M., \& Ihendinihu, J.U. 2016. Effect of Corporate Governance and Ownership Structure on Earnings Management of Brewery Industry. European Journal of Accounting, Auditing and Finance Research 4(7): 35-45.

Parveen, S., Malik, N., Mahmood, Y., \& Jan, F. A. 2016. Impact of Ownership Structure on Earnings Management: Evidence from Pakistani Banking Sector. Journal of Poverty, Investment and Development 23: 24-34.

Pongsaporamamat, P. 2016. Ownership Structure and quality of financial reporting in Thailand: The empirical evidence from accounting restatement Perspective. International Journal of Applied Business and Economics Research 14(10): 6799-6810.

Rafique, Q., Abdullah, Y., \& Margurite Hook 2017. The impact of ownership structure on financial reporting quality in the East. International Journal of Organizational Analysis 25(2):1-20.

Rehman, I.U., Shahzad, F., \& Mahdzan, N.S (2014). The economic consequences of mandatory IFRS reporting: emerging market perspective. Engineering Economics 25 (4): 1-22.

Roodposhti, F. R., \& Chashmi, S. A. N. 2011. The impact of corporate governance mechanisms on earnings management. African Journal of Business Management 5(11): 4143-4151.

Roychowdhury, S. 2006. Earnings management through real activities manipulation. Journal of Accounting and Economics 42(3): 335-370.

Sakaki, H., Jackson, D., \& Jory, S. 2017. Institutional ownership stability and real earnings management. Review of Quantitative Finance and Accounting 49 (1): 227-244.

Saradis, V. \& D. Robertson 2009. On the impact of error cross-sectional dependence in short dynamic panel estimation. The Econometrics Journal 12: 62-81

Schulze, W.,Lubattin, M \& Dino, R. 2003. Exploring the agency consequences of ownership dispersion among the directors of family firms. The Academy of Management Journal 46(2): 179-194.

Shah, Z.S., Butt, A.S., \& Hassan, A. 2009. Corporate Governance and Earnings Management an Empirical Evidence Form Pakistani Listed Companies. European Journal of Scientific Research 26(4): 624-638.

Shah, F., Rashid, A., \& Shahzad, F. 2019. Does board structure improve financial reporting quality? Evidence of real earnings manipulation among Pakistani firms. Abasyn Journal of Social Sciences 12(2): 311-328.

Shayan-Nia M., Sinnadurani, P., Mohd Sanusi, Z \& Hermawan, A. 2017. How efficient ownership structure monitors income manipulation? Evidence of real earnings management among Malaysian firms. Research in International Business and Finance: 1-26.

Shleifer, A., \& Vishny, R.W. 1997. A survey of Corporate Governance. Journal of Finance 52: 737-783.

Teshima, N. \& Shuto, A. 2008. Managerial ownership and earnings management: Theory and empirical evidence from Japan. Journal of International Financial Management and Accounting 19 (2): 107-132.

Udin, S., Khan, M. \& Javid, A. 2017. The effects of ownership structure on likelihood of financial distress: an empirical evidence. Corporate Governance 17 (4): 589-612.

Velury, U., \& Jenkins, D. 2006. Institutional ownership and the quality of earnings. Journal of Business Research 59: $376-424$.

Wajid, H \& Shah, S.A. 2017. The influence of corporate governance and ownership structure on capital structure of Pakistani listed companies. Journal of Contemporary Management Sciences 1(2):31-46.

Wang, D. 2006. Founding family ownership and earnings quality. Journal of Accounting Research 44(3): 619-656.

Wang, L \& Yung, K. 2011. Do state enterprises manage earnings more than privately owned firms? The case of China. Journal of Business Finance and Accounting 88(7): 794-881. 
Yang, C.Y, Lai, H.N \& Tan, B.L 2008. Managerial Ownership Structure and Earnings Management. Journal of Financial Reporting \& Accounting 6(1):35-53.

Yasmeen, D., \& Hermawati, S. 2015. Pengaruh Good Corporate Governance Terhadap Kualitas Pelaporan Keuangan Pada Perusahaan Manufaktur. Jurnal Ekonomi Bisnis 20(1): 25-31.

Zang, A. Y. 2012. Evidence on the Trade-Off between Real Activities Manipulation and Accrual-Based Earnings Management. The Accounting Review 87(2): 675-703.

Zeff, S. A. 2013. The objectives of financial reporting: a historical survey and analysis. Accounting and Business Research 43(4): 262-327.

Syed Farhan Shah*

$\mathrm{PhD}$ (Scholar)

Quaid-i-Azam School of Management Sciences

Quaid-i-Azam University, Islamabad

PAKISTAN

E-mail: shahfarhan@hotmail.co.uk

Abdul Rashid

International Institute of Islamic Economics (IIIE)

International Islamic University, Islamabad

PAKISTAN

E-mail: abdulrashid@iiu.edu.pk

Wasim Shahid Malik

School of Economics

Quaid-i-Azam University, Islamabad

PAKISTAN

E-mail: wsmalik@gmail.com

Faisal Shahzad

Department of management

COMSATS University, Attock Campus

PAKISTAN

E-mail: faisalnoorshah81@gmail.com

*Corresponding author 